\title{
Beneficial effect of Flos magnoliae extract on multiple low dose streptozotocin-induced type 1 diabetes development and cytokine-induced B-cell damage
}

\author{
EUN-KYUNG KIM ${ }^{1 *}$, MI-YOUNG SONG ${ }^{1 *}$, IN-SEOB KIM ${ }^{2}$, WOO SUNG MOON ${ }^{3}$, \\ DO-GON RYU ${ }^{2}$, HONG-SEOB SO ${ }^{4}$, RAEKIL PARK ${ }^{4}$, JIN-WOO PARK ${ }^{1}$, \\ KANG-BEOM KWON ${ }^{2,4}$ and BYUNG-HYUN PARK ${ }^{1}$
}

\begin{abstract}
Departments of ${ }^{1}$ Biochemistry, and ${ }^{3}$ Pathology, Medical School and Institute for Medical Sciences, Chonbuk National University, Jeonju, Jeonbuk 561-756; ${ }^{2}$ Department of Physiology, School of Oriental Medicine, and ${ }^{4}$ Vestibulocochlear System Research Center and Department of Microbiology, College of Medicine, Wonkwang University, Iksan, Jeonbuk 570-749, Korea
\end{abstract}

Received June 9, 2008; Accepted July 28, 2008

DOI: $10.3892 /$ ijmm_00000046

\begin{abstract}
In the present study, Flos magnoliae extract (FME) was evaluated to determine if it could protect pancreatic B-cells against multiple low dose streptozotocin (MLDS) and interleukin- $1 \beta$ and interferon- $\gamma$. Injection of mice with MLDS resulted in hyperglycemia and hypoinsulinemia, which was confirmed by immunohistochemical staining. However, the induction of diabetes by MLDS was completely prevented when mice were pretreated with FME. FME also effectively protected $\beta$-cells against cytokine toxicity, which was demonstrated by an increase in the viability of rat insulinoma RINm5F cells and by preserved insulin secreting responses to glucose in isolated rat islets. Moreover, cytokine-induced nitric oxide production and iNOS mRNA and protein expression were significantly reduced in RINm5F cells and islets that were preincubated with FME. The molecular mechanism by which FME inhibits iNOS gene expression in in vitro and in vivo appears to involve inhibition of NF-kB activation. Taken together, these results reveal the possible therapeutic value of FME for the prevention of type 1 diabetes progression.
\end{abstract}

Correspondence to: Dr Byung-Hyun Park, Medical School, Chonbuk National University, Jeonju, Jeonbuk 561-756, Korea E-mail: bhpark@chonbuk.ac.kr

Dr Kang-Beom Kwon, School of Oriental Medicine, Wonkwang University, Iksan, Jeonbuk 570-749, Korea

E-mail: desson@wonkwang.ac.kr

${ }^{*}$ Contributed equally

Key words: Flos magnoliae extract, streptozotocin, cytokine, nuclear factor $\kappa \mathrm{B}, \beta$-cell

\section{Introduction}

Insulin-dependent diabetes mellitus (IDDM) is an autoimmune disease that results from the selective destruction of pancreatic B-cells (1). During early stages of the disease, histological findings reveal features of insulitis, which is characterized by the infiltration of immune cells such as $\mathrm{T}$ lymphocytes, macrophages, and natural killer cells into pancreatic islets $(2,3)$. These infiltrated cells then produce and release various cytokines, which act as humoral mediators of the immunologic process. Therefore, cytokines such as interleukin- $1 \beta$ (IL-1ß), tumor necrosis factor- $\alpha$, and interferon- $\gamma$ (IFN- $\gamma$ ) have been implicated as key effector molecules in $\beta$-cell function and viability (4). IL-1ß alone or in combination with tumor necrosis factor- $\alpha$ or IFN- $\gamma$ upregulates inducible nitric oxide synthase (iNOS) and produces high levels of nitric oxide (NO) in pancreatic islets $(5,6)$. NO is produced by the oxidation of L-arginine to L-citruline by nitric oxide synthase (NOS), and excess NO is known to inhibit mitochondrial metabolism, to modify protein, and to cleave DNA $(7,8)$.

Alloxan and streptozotocin (STZ) are two agents commonly used to induce diabetes. These structurally diverse compounds have a long history of use in diabetes research and are known to be specifically toxic to pancreatic $\beta$-cells (9). Alloxan is thought to produce oxygen-free radicals (10), whereas STZ contains a nitroso moiety and releases NO during its metabolism (11-13). STZ induces B-cell damage by two different mechanisms according to the concentrations used (14). A single high dose of STZ rapidly destroys B-cells via direct cytotoxic action that occurs primarily as a result of alkylation and cleavage of the DNA (15). Multiple low doses of STZ (MLDS) activates immune mechanisms and induces inflammation of the islets. There is evidence that NO mediates the deleterious effects of MLDS on B-cell dysfunction and destruction $(16,17)$, and Flodstrom et al (18) reported that iNOS knock-out mice are resistant to the induction of diabetes by MLDS. 
The transcriptional nuclear factor $\kappa \mathrm{B}(\mathrm{NF}-\kappa \mathrm{B})$, which can be activated by cytokine and STZ, is a key signaling mediator of iNOS induction (19-21). The importance of NF-kB in MLDS is underscored by the fact that mice that do not possess the p50 subunit of NF- $\mathrm{KB}$ are not susceptible to MLDSinduced diabetes (22). In addition, we previously demonstrated that NF-кB-dependent iNOS expression played a key role in the dysfunction and destruction of B-cells (21).

The flower buds of Magnolia denudata Desrousseaux, which are known as Flos magnoliae, are commonly used in traditional Chinese medicine to treat nasal congestion with headache, sinusitis and allergic rhinitis. Moreover, it has been reported that Flos magnoliae extract (FME) has an antiangiogenic (23) and an anti-inflammatory effect (24). In this study, we demonstrated that FME inhibited the development of type 1 diabetes, indicating that FME has the potential for use as a therapeutic agent to treat diabetes.

\section{Materials and methods}

Cell culture. RINm5F (RIN) cells were purchased from the American Type Culture Collection and grown at $37^{\circ} \mathrm{C}$ under a humidified, $5 \% \mathrm{CO}_{2}$ atmosphere in RPMI-1640 medium (HyClone, South Logan, UT) supplemented with $10 \%$ fetal bovine serum and $2 \mathrm{mM}$ glutamine, 100 units $/ \mathrm{ml}$ of penicillin, $100 \mu \mathrm{g} / \mathrm{ml}$ of streptomycin and $2.5 \mu \mathrm{g} / \mathrm{ml}$ of amphotericin B.

Preparation of Flos magnoliae extract. The plant was purchased from Wonkwang Oriental Medical Hospital in Iksan, Jeonbuk, Korea and identified as Flos magnoliae by Ho-Joon Song, keeper of the Herbarium. Voucher samples were preserved for reference in the Herbarium of the Department of Physiology, School of Oriental Medicine, Wonkwang University (Omcphy, 2005-82). For extraction, $200 \mathrm{~g}$ of Flos magnoliae was ground and extracted in boiling water for $4 \mathrm{~h}$. The sample was then centrifuged at 3,000 x g for $20 \mathrm{~min}$, after which the supernatant was concentrated to $200 \mathrm{ml}$ under reduced pressure and then freeze dried to $16.8 \mathrm{~g}$. The sterile extract was then stored at $-70^{\circ} \mathrm{C}$ until use.

Animals. Specific pathogen-free female ICR mice were purchased from Orientbio Inc. (Seoungnam, Korea) and housed at our animal facility for one week prior to use. All mice used were 5-6 weeks old, and were kept under specific pathogen-free conditions with free access to a standard commercial diet. To induce diabetes, the mice received an i.p. injection of freshly prepared STZ $(50 \mathrm{mg} / \mathrm{kg}$ body weight; $0.2 \mathrm{ml}$ ) dissolved in sodium citrate buffer ( $\mathrm{pH} 4.0)$ once a day, for 5 consecutive days. In addition, some mice were administered $250 \mathrm{mg} / \mathrm{kg}$ FME daily by oral gavage for 3 days prior to being administered the STZ injections. The mice were divided into the following groups: i) the non-treated control group, ii) the MLDS group, and iii) the FME + MLDS group ( $n=5$, each group). The day on which the first STZ injection was administered is defined as day 1. Control group animals were administered citrate buffer alone. At day 5, the mice were sacrificed by decapitation without anesthesia, and the trunk blood was collected in prechilled tubes that contained $1 \mathrm{mg} / \mathrm{ml}$ of EDTA. The plasma glucose was then assayed by the glucose oxidase method (Sigma, St. Louis, MO), and the plasma insulin was measured using an ELISA kit (Linco Research, St. Charles, MO). All experimental procedures were approved by the Institutional Animal Care and Use Committee at Chonbuk National University.

Immunohistochemistry. The Dako Envision system (Dako, Carpinteria, CA), which used dextran polymers conjugated with horseradish peroxidase, was employed for immunohistochemical staining to avoid any endogenous biotin contamination. The pancreases were removed from the sacrificed mice, and then immediately fixed in 0.1 M PBS that contained $10 \%$ formalin. The fixed samples were then embedded in paraffin tissue blocks, after which 4- $\mu \mathrm{m}$ histologic sections were cut. Next, the samples were deparaffinized, after which the tissue sections were placed in $10 \mathrm{mM}$ sodium citrate and treated using the microwave antigen retrieval procedure. The endogenous peroxidase was then blocked, after which the sections were then incubated with Protein Block Serum-Free (Dako) to block nonspecific staining. The sections were then incubated with anti-insulin antibody (Santa Cruz Biochemicals, Santa Cruz, CA), after which the peroxidase activity was detected using the enzyme substrate 3-amino-9-ethyl carbazole.

MTT assay for cell viability. The viability of cultured cells was determined by assaying the reduction of 3-(4,5dimethylthiazol-2-yl)-2,5-diphenyltetrazolium bromide (MTT) to formazan. Briefly, the cells were treated with cytokine for 24 or $48 \mathrm{~h}$, after which they were washed twice with PBS. Next, MTT (100 $\mu \mathrm{g} / 100 \mu \mathrm{l}$ of PBS) was added, and the cells were then incubated at $37^{\circ} \mathrm{C}$ for $1 \mathrm{~h}$, after which DMSO (100 $\left.\mu \mathrm{l}\right)$ was added to dissolve the formazan crystals. The absorbance was then measured at $570 \mathrm{~nm}$ using a spectrophotometer.

\section{5-Bromo-2-deoxyuridine (BrdU)-labeling cell proliferation} assay. A cell proliferation enzyme-linked immunosorbant assay (BrdU kit; Amersham Biosciences, Piscataway, NJ) was used to measure the incorporation of BrdU during DNA synthesis following the manufacturer's protocols. Briefly, following treatment with cytokine for 24 or $48 \mathrm{~h}$, BrdU $(10 \mu \mathrm{M})$ was added to the culture medium for $2 \mathrm{~h}$. Next, the BrdU-labeled cells were fixed, and the DNA was then denatured in fixative solution for $30 \mathrm{~min}$ at room temperature. The cells were then incubated with peroxidase-conjugated anti-BrdU antibody for $2 \mathrm{~h}$ at room temperature, followed by washing three times with washing solution. The immune complex was then detected by inducing a 3,3',5,5'-tetramethylbenzidine substrate reaction and then measuring the absorbance at $405 \mathrm{~nm}$.

NO measurement. Biologically produced NO is rapidly oxidized to nitrite and nitrate in aqueous solutions (25). Therefore, NO production was evaluated by measuring the nitrite concentrations in the cell-free culture supernatant using a colorimetric assay. Briefly, following treatment with cytokine for $24 \mathrm{~h}, 100-\mu 1$ aliquots of the culture supernatants were incubated with $100 \mu \mathrm{l}$ of a modified Griess reagent $(1: 1$ mixture of $1 \%$ sulfanilamide in $30 \%$ acetic acid and $0.1 \% \mathrm{~N}$ (1-naphthyl)ethylenediamine dihydrochloride in $60 \%$ acetic acid) at room temperature for $5 \mathrm{~min}$, at which time the 
absorbance at $540 \mathrm{~nm}$ was measured using a spectrophotometer. The concentrations of NO were then determined using a linear standard curve generated from serial dilutions of sodium nitrite in working medium.

RNA isolation and real-time PCR for iNOS. Total RNA was isolated from RIN cells or islets using Trizol reagent (Invitrogen, Carlsbad, CA). The RNA was then precipitated with isopropanol and dissolved in DEPC-treated distilled water. The total RNA $(2 \mu \mathrm{g})$ was then treated with RNasefree DNase (Invitrogen), after which first-strand cDNA was generated using the random hexamer primer provided in the first-strand cDNA synthesis kit (Applied Biosystems, Foster City, CA). The following specific primers for iNOS were designed using the primer express software (Applied Biosystems): iNOS (accession no. NM_012611), 5'-TGTGC TAATGCGGAAGGTCAT-3' (forward), and 5'-CGACTTT CCTGTCTCAGTAGCAAA-3' (reverse). The sequence for the control 18S ribosomal RNA was purchased from Applied Biosystems and used as the invariant control. A reaction mixture with a final volume of $10 \mu \mathrm{l}$ that contained $10 \mathrm{ng}$ of reverse transcribed total RNA, $167 \mathrm{nM}$ of forward and reverse primers and 2X PCR Master mix was then subjected to realtime PCR, which was conducted in 384-well plates using an ABI PRISM 7900HT Sequence Detection System (Applied Biosystems). All reactions were conducted in triplicate.

Western blot analysis. Cells or islets were homogenized in $100 \mu \mathrm{l}$ of ice-cold lysis buffer (20 mM HEPES, pH 7.2, $1 \%$ Triton X-100, 10\% glycerol, $1 \mathrm{mM}$ PMSF, $10 \mu \mathrm{g} / \mathrm{ml}$ leupeptin and $10 \mu \mathrm{g} / \mathrm{ml}$ aprotinin). The homogenates, which contained $20 \mu \mathrm{g}$ of protein, were then separated by SDS-PAGE with $7.5 \%$ (for iNOS) or $12 \%$ resolving (for $\operatorname{I\kappa B} \alpha, \mathrm{p} 65$, $\beta$-actin and PCNA) and 3\% acrylamide stacking gels, after which they were transferred to nitrocellulose sheets. Next, the nitrocellulose paper was blocked with $2 \%$ bovine serum albumin and then incubated for $4 \mathrm{~h}$ with $1 \mu \mathrm{g} / \mathrm{ml}$ of primary antibody (Santa Cruz Biochemicals). Horseradish peroxidaseconjugated IgG (Zymed, South San Francisco, CA) was used as a secondary antibody. The protein expression levels were then determined by analyzing the signals captured on the nitrocellulose membranes using a Chemi-doc image analyzer (Bio-Rad, Hercules, CA).

Preparation of nuclear extracts. After treatment with cytokine or STZ, cells or pancreatic tissues were homogenized and washed twice with ice-cold PBS ( $\mathrm{pH} 7.9)$ and then pelleted by centrifugation at $12,000 \mathrm{x}$ g for $30 \mathrm{sec}$. Next, the pellet was suspended in cold hypotonic lysis buffer (10 mM HEPES, $1.5 \mathrm{mM} \mathrm{MgCl} 2,0.2 \mathrm{mM} \mathrm{KCl}, 0.2 \mathrm{mM}$ PMSF and $0.5 \mathrm{mM}$ dithiothreitol), vortexed for $10 \mathrm{sec}$, and then incubated on ice for $15 \mathrm{~min}$. The packed cells were then re-suspended in icecold hypotonic lysis buffer in the presence of $50 \mu 1$ of $10 \%$ Nonidet P-40, after which they were incubated on ice for $25 \mathrm{~min}$. Next, the nuclear fraction was precipitated by centrifugation at $13,000 \mathrm{x}$ g for $1 \mathrm{~min}$ at $4^{\circ} \mathrm{C}$, after which the supernatants (cytosol extracts) were collected and stored at $-80^{\circ} \mathrm{C}$. The pelleted nuclei were then re-suspended in 50-100 $\mu \mathrm{l}$ of low salt extraction buffer (20 mM HEPES, pH 7.9, $1.5 \mathrm{mM}$ $\mathrm{MgCl}_{2}, 25 \%$ glycerol, $20 \mathrm{mM} \mathrm{KCl}, 0.2 \mathrm{mM}$ EDTA, $0.2 \mathrm{mM}$
PMSF and 0.5 mM dithiothreitol), added to an equal volume of high salt extraction buffer (20 mM HEPES, pH 7.9, $1.5 \mathrm{mM}$ $\mathrm{MgCl}_{2}, 25 \%$ glycerol, $80 \mathrm{mM} \mathrm{KCl}, 0.2 \mathrm{mM}$ EDTA, $0.2 \mathrm{mM}$ PMSF and $0.5 \mathrm{mM}$ dithiothreitol) in a dropwise fashion, and then incubated under continuous shaking at $4^{\circ} \mathrm{C}$ for $45 \mathrm{~min}$. The sample was then centrifuged for $20 \mathrm{~min}$ at $12,000 \mathrm{x} \mathrm{g}$. $\mathrm{Next}$, the protein concentrations of the samples were determined, after which aliquots of the nuclear extracts were stored at $-80^{\circ} \mathrm{C}$ until needed.

Electrophoretic mobility shift assay (EMSA). The activation of NF-кB was assayed by a gel mobility shift assay using nuclear extracts from control and treated cells. Briefly, an oligonucleotide containing the $\kappa$-chain binding site $\left(\kappa \mathrm{B}, 5^{\prime}-\mathrm{CC}\right.$ GGTTAACAGAGGGGGCTTTCCGAG-3') was synthesized and used as a probe for a gel retardation assay. The two complementary strands were then annealed and labeled with $\left[\alpha{ }^{-32} \mathrm{P}\right] \mathrm{dCTP}$. The labeled oligonucleotides $(10,000 \mathrm{cpm}), 10 \mu \mathrm{g}$ of nuclear extracts and binding buffer $(10 \mathrm{mM}$ Tris- $\mathrm{HCl}$, pH 7.6, $500 \mathrm{mM} \mathrm{KCl,} 10 \mathrm{mM}$ EDTA, 50\% glycerol, $100 \mathrm{ng}$ poly $(\mathrm{dI} \cdot \mathrm{dC}), 1 \mathrm{mM}$ dithiothreitol) were then incubated for $30 \mathrm{~min}$ at room temperature in a final volume of $20 \mu 1$. Next, the reaction mixtures were analyzed by electrophoresis on $4 \%$ polyacrylamide gels in $0.5 \mathrm{X}$ Tris-borate buffer, after which the gels were dried and examined by autoradiography.

Isolation of islets and insulin secretion assay. Pancreatic islets were isolated from male Sprague-Dawley rats using the collagenase digestion method, as described previously (26). Briefly, the cells were treated with cytokine for $24 \mathrm{~h}$, after which the islets were washed three times in Krebs-Ringer bicarbonate buffer (25 mM Hepes, $115 \mathrm{mM} \mathrm{NaCl}, 24 \mathrm{mM}$ $\mathrm{NaHCO}_{3}, 5 \mathrm{mM} \mathrm{KCl}, 1 \mathrm{mM} \mathrm{MgCl}, 2.5 \mathrm{mM} \mathrm{CaCl}_{2}$, and $0.1 \%$ bovine serum albumin, $\mathrm{pH} 7.4$ ) containing $3 \mathrm{mM}$ $\mathrm{D}$-glucose. The insulin secretion was then measured by static incubation of the islets for $30 \mathrm{~min}$ in the presence of either 5.5 or $20 \mathrm{mM}$ D-glucose. The insulin content of the medium was then determined by ELISA.

Statistical analysis. Statistical analysis of the data was performed using ANOVA and Duncan's test. Differences with a $\mathrm{p}<0.05$ were considered statistically significant.

\section{Results}

FME has an anti-diabetic effect in mice. Mice that were injected with MLDS gradually became hyperglycemic (i.e. fasting blood glucose concentrations $\geq 126 \mathrm{mg} \%$ ), with an increased incidence of diabetes being observed from day 3 onwards. The blood glucose level of the mice that were injected with MLDS at day 3 was $214.3 \pm 20.3 \mathrm{mg} \%$; however, the mice that were pretreated with FME were fully resistant to the development of diabetes (Fig. 1A). In addition, treatment with FME alone did not affect the blood glucose concentration in mice (data not shown). Furthermore, the plasma insulin level at day 5 in the MLDS group decreased by $82.4 \%$ (from $6.32 \pm 0.41$ to $1.11 \pm 0.12 \mathrm{ng} / \mathrm{ml}$ ), whereas the severity of hypoinsulinemia was attenuated in mice that were pretreated with FME (Fig. 1B). These results indicate that FME is protective against MLDS-induced diabetes. 
A

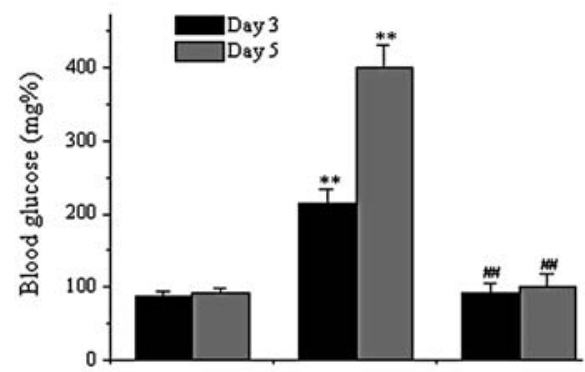

B

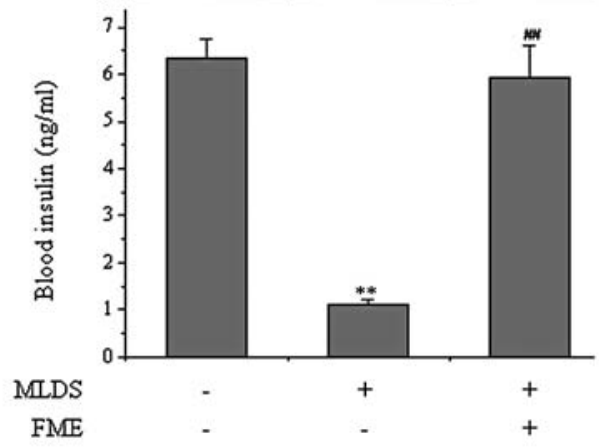

$\mathrm{C}$

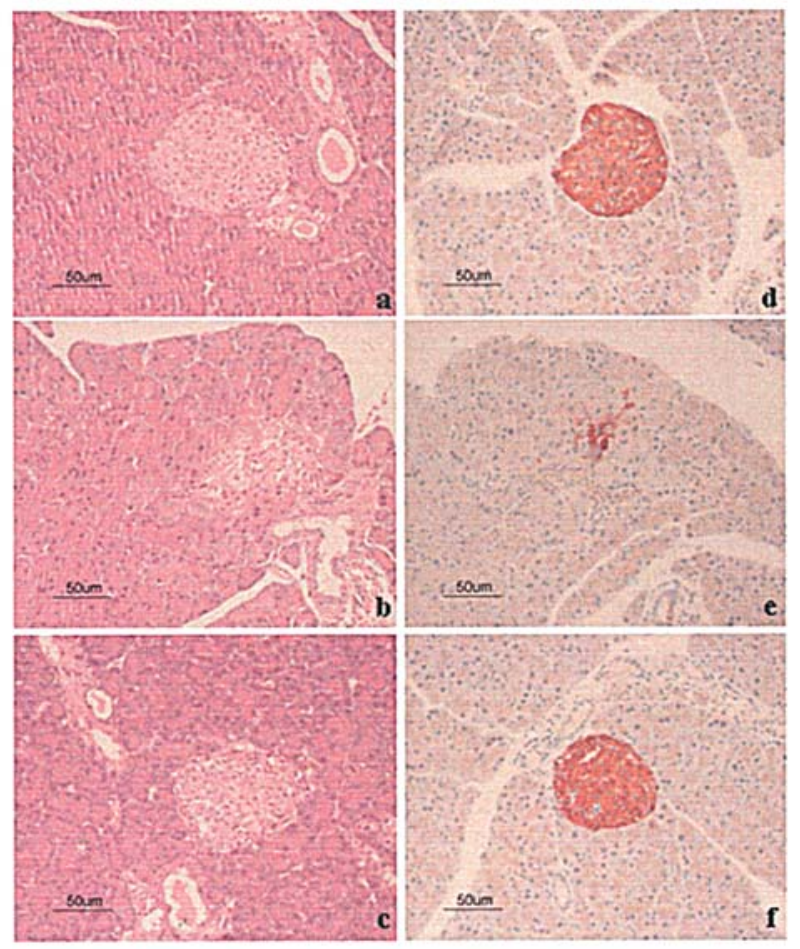

Figure 1. FME protects islets from MLDS-induced destruction. ICR mice were injected with FME via oral administration of a daily dose of $250 \mathrm{mg} / \mathrm{kg}$ for 3 days, and then injected with STZ $(50 \mathrm{mg} / \mathrm{kg}$ ) via i.p. daily for 5 days. Levels of fasting glucose (A) and insulin were then determined (B). (C) Pancreases were obtained from normal controls (a, d), STZ-injected (b, e), and FME and STZ-injected mice (c, f). The cellular morphologies of these islets and of the adjoining exocrine regions were then counterstained with $\mathrm{H} \& \mathrm{E}(\mathrm{a}-\mathrm{c})$. Islets were labeled for insulin antibody and peroxidaselabeled anti-rabbit IgG and then examined by microscopy (d-f). (D) Nuclear extracts from pancreatic tissues were prepared 5 days after STZ injection and the DNA binding of NF- $\mathrm{kB}$ was analyzed by EMSA. ${ }^{* *} \mathrm{p}<0.01$ vs. untreated control; ${ }^{\#} \mathrm{p}<0.01$ vs. STZ-injected group.

The preventive effect of FME on MLDS-induced diabetes was histologically examined. Pancreatic tissues were obtained 5 days after MLDS administration with or without FME
D

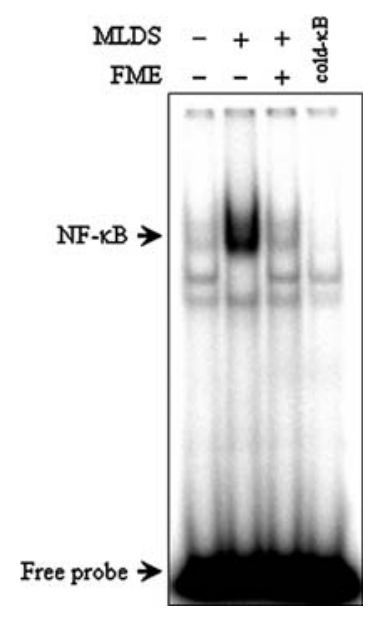

pretreatment and then subjected to $H \& E$ staining and immunohistochemistry. H\&E staining revealed that diabetic mice had degenerative and necrotic changes and islet shrinkage (Fig. 1C, b), as well as weak insulin-reactivity in a few B-cells (Fig. 1C, e). However, H\&E staining and immunohistochemistry of samples collected from diabetic mice that were pretreated with FME revealed the presence of round, nearly normal and clearly defined islets that were strongly positive for insulin (Fig. 1C, c and f).

To elucidate the anti-diabetogenic mechanism of FME, we examined its effect on MLDS-induced NF- $\mathrm{KB}$ activation. The findings of this investigation were similar to those of a previous study, which demonstrated that STZ treatment resulted in NF- $\kappa B$ activation in mice (27). Fig. 1D is a representative EMSA radiograph showing the ${ }^{32} \mathrm{P}-\mathrm{DNA} / \mathrm{NF}-\mathrm{kB}$ complex in nuclear extracts of the pancreas 5 days after MLDS administration. In contrast, this complex was not detected in nuclear extracts obtained from the pancreases of FMEpretreated mice. Taken together, these results show that FME inhibits the translocation of NF- $\mathrm{KB}$ to the nucleus in mice.

FME prevents cytokine-mediated cell death by RIN cells. We next investigated the anti-diabetogenic effect of FME at the cellular level. Based on a previous study (28), a cytokine mix consisting of IL-1ß $(5 \mathrm{ng} / \mathrm{ml})$ and IFN- $\gamma(100 \mathrm{U} / \mathrm{ml})$ was employed throughout the current study to maintain the stable toxic effectiveness of the cytokine exposure protocol. RIN cells from a rat pancreatic $\beta$-cell line were cultured to near confluence and then cells that had been pretreated with or without FME for $3 \mathrm{~h}$ were exposed to cytokine for 24 or $48 \mathrm{~h}$, after which their viability was assessed using MTT assay. Treatment with cytokine significantly reduced the cell viability to $45.6 \pm 1.1 \%$ at $24 \mathrm{~h}$ and $22.0 \pm 0.4 \%$ at $48 \mathrm{~h}$ when compared to that of the control (Fig. 2A). Conversely, FME increased the viability of cytokine-treated RIN cells in a concentrationdependent manner. The beneficial effect of FME on cytokineinduced viability reduction was further confirmed by evaluating the BrdU incorporation in RIN cells. Treatment with cytokine for 24 and $48 \mathrm{~h}$ reduced the level of BrdU incorporation, and therefore proliferation, to $56.9 \pm 6.1$ and $36.7 \pm 4.0 \%$ of the control levels, respectively. Similar to the MTT assay data, FME prevented the cytokine-mediated 
A

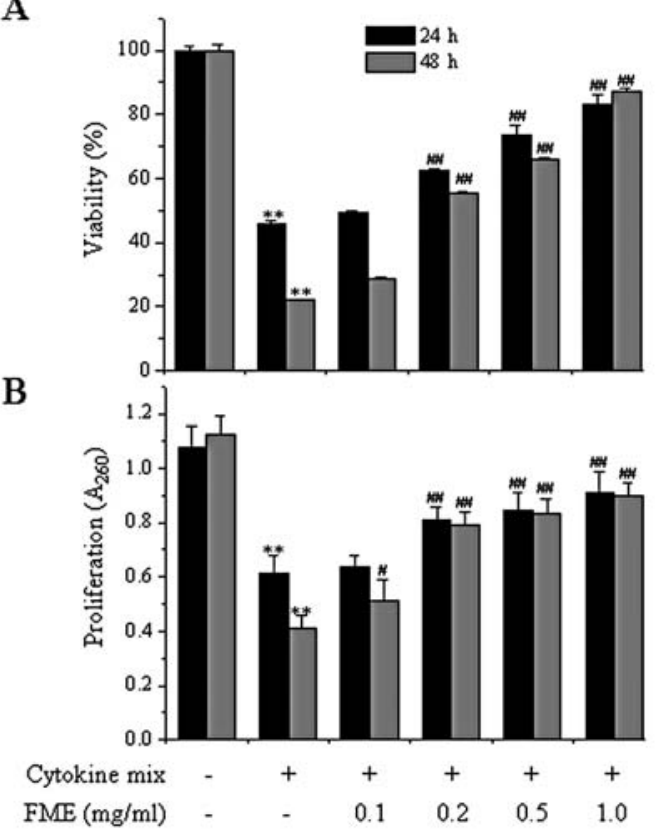

Figure 2. FME prevents cytokine-induced cell death in RIN cells. RIN cells were pretreated with the indicated concentrations of FME for $3 \mathrm{~h}$, and IL-1B $(5 \mathrm{ng} / \mathrm{ml})$ and IFN- $\gamma(100 \mathrm{U} / \mathrm{ml})$ were added for 24 or $48 \mathrm{~h}$. The cell viability and cell proliferative potential were determined by MTT (A) and a BrdU incorporation assay (B), respectively. Each value is the mean \pm SEM of three independent experiments. ${ }^{* *} \mathrm{p}<0.01$ vs. untreated control; ${ }^{*} \mathrm{p}<0.05$, ${ }^{\# \#} \mathrm{p}<0.01$ vs. IL- $1 \beta+\mathrm{IFN}-\gamma$.
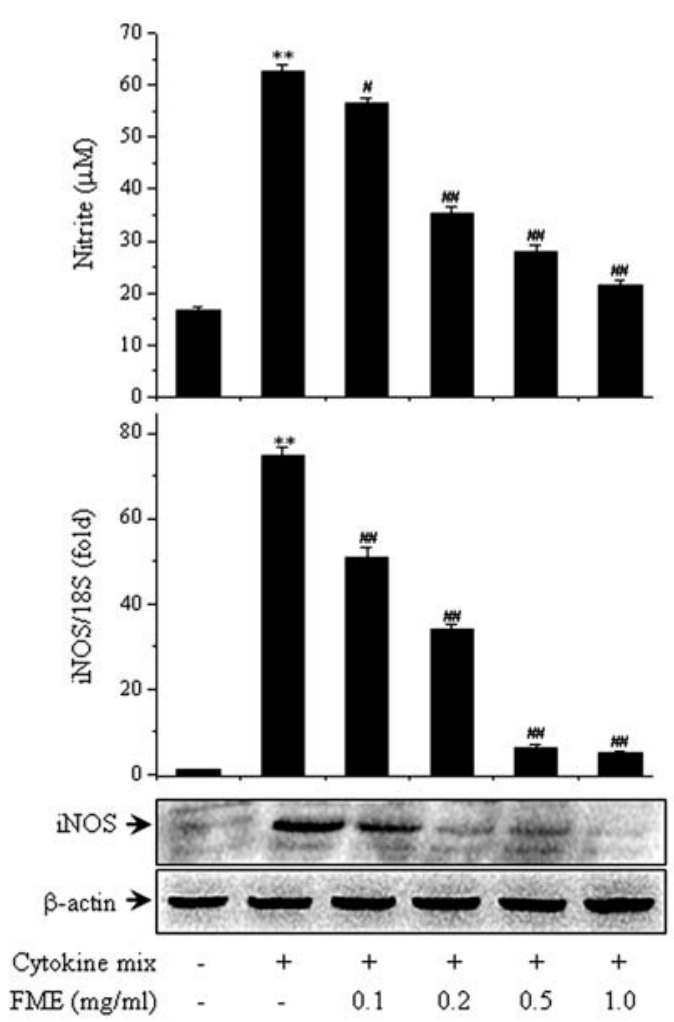

Figure 3. FME inhibits cytokine-induced NO production and iNOS expression in RIN cells. RIN cells were pretreated with the indicated concentrations of FME for $3 \mathrm{~h}$, after which IL- $1 \beta$ and IFN- $\gamma$ were added. Following $24 \mathrm{~h}$ of incubation, the level of nitrite production and iNOS mRNA and protein expression were determined. Results of triplicate samples are expressed as the mean \pm SEM. ${ }^{* *} \mathrm{p}<0.01$ vs. untreated control; ${ }^{*} \mathrm{p}<0.05,{ }^{\#} \mathrm{p}<0.01$ vs. IL- $1 \beta$ + IFN $-\gamma$.
A

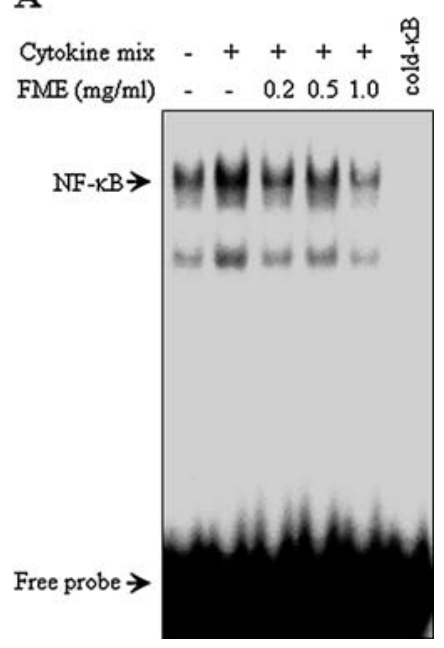

B

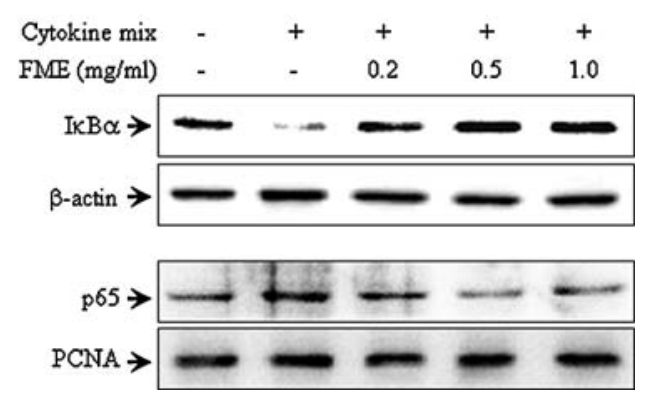

Figure 4. FME inhibits cytokine-induced DNA binding of NF- $\kappa B$, translocation of $\mathrm{p} 65$ to the nucleus, and IкB $\alpha$ degradation in RIN cells. RIN cells were pretreated with the indicated concentrations of FME for $3 \mathrm{~h}$, after which cytokine was added. Following $30 \mathrm{~min}$ of incubation, DNA binding of NF-кB was analyzed by EMSA (A), and the translocation of p65 to the nucleus and IкB $\alpha$ degradation in the cytoplasm (B) were determined by Western blotting. B-actin and PCNA were used as loading controls for cytosolic and nuclear proteins, respectively.

decrease in cell proliferation potential in a concentrationdependent manner (Fig. 2B). Furthermore, treatment with FME alone did not affect cell viability at the concentrations used in this study (data not shown).

FME inhibits cytokine-mediated iNOS expression by inhibiting $N F-\kappa B$. NO production under the same conditions was also evaluated. Control RIN cells generated $16.8 \pm 0.5 \mu \mathrm{M}$ of nitrite, whereas cytokine-treated cells generated $62.6 \pm 1.3 \mu \mathrm{M}$ of nitrite in $24 \mathrm{~h}$ (Fig. 3). Conversely, a concentration-dependent reduction in cytokine-mediated nitrite production was observed in RIN cells treated with cytokine plus FME. Near complete inhibition of nitrite production was observed in cells that were pretreated with $1.0 \mathrm{mg} / \mathrm{ml}$ FME. Furthermore, nitrite production was not observed in cells that were treated with FME alone (data not shown).

To investigate the regulating effect of FME on NO production, we examined the effects of FME on cytokineinduced iNOS mRNA and protein expression using real-time PCR and Western blotting, respectively. As shown in Fig. 3, cytokine increased iNOS mRNA and protein levels. However, when cells were treated with FME prior to cytokine treatment, the iNOS mRNA and protein levels were reduced in a dose- 


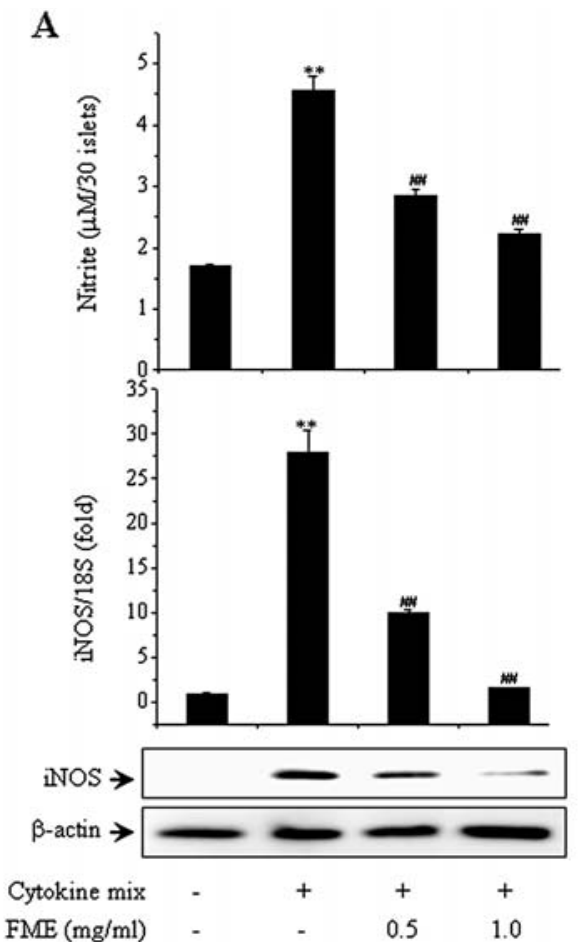

B

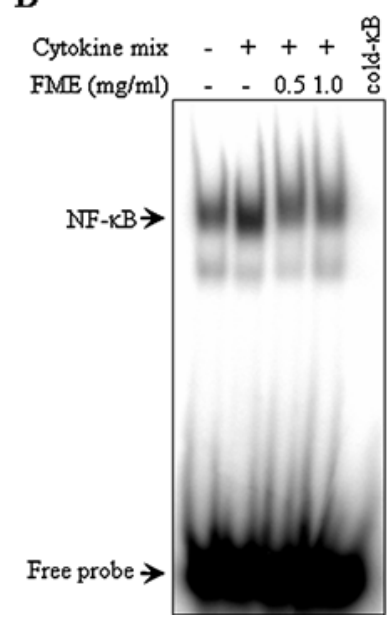

Figure 5. FME inhibits cytokine-induced activation of the NF- $\mathrm{B}$ pathway and restores glucose-stimulated insulin secretion in rat islets. Rat islets (30 islets total) were treated with cytokine with or without a $3 \mathrm{~h}$ pretreatment with the indicated concentrations of FME. Nitrite production and iNOS mRNA and protein expression (A) were determined $24 \mathrm{~h}$ later, and DNA binding of NF- $\mathrm{KB}$ (B) was then determined 30 min later. Rat islets (10 islets $/ 500 \mu \mathrm{l}$ ) were treated with cytokine with or without a $3 \mathrm{~h}$ pretreatment with the indicated concentrations of FME. Following $24 \mathrm{~h}$ of incubation, glucose-stimulated insulin secretion was quantified (C). The results of triplicate samples are expressed as the mean \pm the SEM. ${ }^{* *} \mathrm{p}<0.01 \mathrm{vs}$. untreated control; ${ }^{\# \#} \mathrm{p}<0.01$ vs. IL- $13+\mathrm{IFN}-\gamma$.

dependent manner with effects being observed in response to treatment with $0.1 \mathrm{mg} / \mathrm{ml}$ of FME, and treatment with $1.0 \mathrm{mg} /$ $\mathrm{ml}$ of FME completely blocking the iNOS mRNA and protein expression.

$\mathrm{NF}-\kappa \mathrm{B}$ has been implicated in the toxicity of MLDS (Fig. 1D), therefore the effect of FME on the cytokinestimulated translocation of $\mathrm{NF}-\mathrm{\kappa B}$ from the cytosol to the nucleus in RIN cells was evaluated. Nuclear extracts from
C

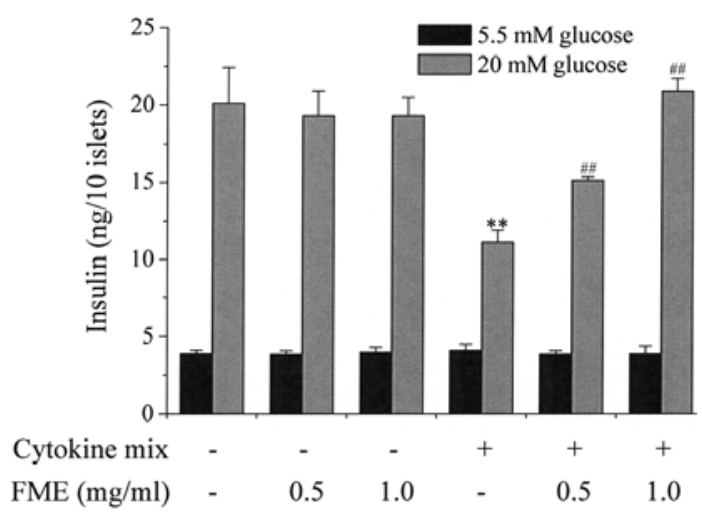

cytokine-stimulated RIN cells showed an increase in NF- $\mathrm{kB}$ binding activity (Fig. 4A, lane 2) as well as an increased p65 subunit level in their nuclei (Fig. 4B) when compared to unstimulated cells. Conversely, cytokine-induced NF-кB activation was markedly suppressed by pretreatment with FME, which suggests that FME inhibits iNOS expression through the inhibition of NF-KB activation. The specificity of the DNA-NF- $\mathrm{BB}$ interaction was demonstrated by competitive assays using a 50 -fold excess of unlabeled oligonucleotide (Fig. 4A, lane 6).

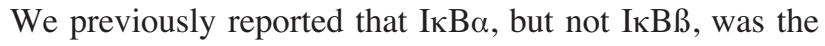
major participant in cytokine-induced NF- $\mathrm{KB}$ activation (21). Therefore, we investigated the alteration of $\mathrm{I} \kappa \mathrm{B} \alpha$ levels in the cytosol fraction following cytokine treatment (Fig. 4B). Cytokine-treated RIN cells showed a decreased level of IкB $\alpha$ protein in the cytosol when compared to a similar fraction of the unstimulated cells; however, the increased IкB $\alpha$ degradation that occurred as a result of cytokine treatment was markedly suppressed by pretreatment with FME.

Suppression of the cytokine-induced $N F-\kappa B$ pathway and preservation of glucose-stimulated insulin secretion (GSIS) by FME in rat islets. We further assayed the preventive effects of FME using rat pancreatic islets isolated from male SpragueDawley rats. Incubation of rat islets for $24 \mathrm{~h}$ with cytokine resulted in a 2.7 -fold increase in NO production (Fig. 5A). Additionally, real-time PCR and Western blot analysis revealed that the iNOS mRNA and protein levels were markedly increased by cytokine (Fig. 5A). Similar to the results obtained using the RIN cells, pretreatment of the islets with FME abolished the effects of cytokine and abrogated the levels of NO production and iNOS expression to those of the control islets. Additionally, treatment with cytokine also increased the NF- $\mathrm{KB}$ DNA binding activity in islets (Fig. 5B), and pretreatment of the islets with FME completely abolished these effects. To add functional data, FME was evaluated to determine if it could protect against cytokine-induced impairment of GSIS. After $24 \mathrm{~h}$ of exposure to the cytokine, insulin secretion was assayed in response to $20 \mathrm{mM}$ glucose. Control islets secreted insulin at a concentration of $20.1 \pm 2.3 \mathrm{ng} /$ $\mathrm{ml}$, whereas insulin secretion from cytokine-treated islets decreased significantly to $11.1 \pm 0.8 \mathrm{ng} / \mathrm{ml}(\mathrm{p}<0.01)$ (Fig. 5C). However, pretreatment with FME blocked the effect of the cytokine and restored islet cell insulin secretion to levels 
similar to those of the control. In addition, treatment with FME alone did not affect the insulin secreting response to glucose.

\section{Discussion}

In this study, we presented a mode of action by which pretreatment with FME resulted in protection against the development of type 1 diabetes in response to MLDS. In addition, B-cell protective effects of FME towards toxic challenge of cytokine in RIN cells and islets were demonstrated.

In the first series of experiments, $N F-\kappa B$ activation in response to injection with MLDS and its prevention by FME was evaluated in mice. An EMSA study revealed that increased $\mathrm{NF}-\kappa \mathrm{B}$ binding activity occurred in pancreatic nuclear extracts derived from MLDS-injected hyperglycemic diabetic mice. $N F-\kappa B$ participates in the transcriptional regulation of cytokine genes, and their activation results in the production of pro-inflammatory cytokine $(29,30)$; therefore, NF- $\mathrm{KB}$ may be a key regulator in the pathway of local cytokine responses involved in MLDS-mediated B-cell destruction. Moreover, it has been reported that $\mathrm{T}$-cell mediated inflammatory reactions are stimulated only in the MLDS model, but not after administration of a single high dose of STZ (9), which suggests that NF- $\mathrm{KB}$ plays a key role in MLDS-induced insulitis in pancreatic islets. MLDS-injected mice also showed marked islet destruction and relatively small numbers of insulin-positive $\beta$-cells, whereas well-defined islets and strong insulin-positive staining were observed in FME pretreated mice. In addition, pretreatment with FME prevented NF- $\mathrm{KB}$ activation, which resulted in the maintenance of plasma glucose and insulin levels during the normal range. Taken together, these results suggest that manipulation of NF- $\kappa$ B activity by FME in pancreatic $\beta$-cells allows these cells to withstand and survive MLDS-mediated immune attack.

Similar effects of FME were observed in RIN cells and rat islets exposed to cytokine. The reduction in NO production by FME in RIN cells or islets was associated with a reduction in $N F-\kappa B$ activation and iNOS mRNA expression. In pancreatic $\beta$-cells, increased NO production in response to $\mathrm{NF}-\kappa \mathrm{B}$ activation appears to be an important signal in cytokine-induced apoptosis because inhibition of iNOS has been shown to prevent apoptosis $(5,6)$. Therefore, the process leading to NO production in response to cytokine has been targeted for the treatment of type 1 diabetes. The effects of NO suppression and the associated reduction in cytokine toxicity induced by FME are similar to the results of previously conducted studies that have found that natural products or dietary supplements reduce iNOS expression and protect $ß$-cells from cytokine toxicity $(28,31-33)$. In addition, chemical donors of NO or cytokine promote ER stress (34), activation of MAPK (32), and activation of the JAK-STAT pathways (33) in B-cells. Therefore, we cannot exclude the possibility that the aforementioned pathways are involved in our system and that the protective effect of FME occurs via the suppression of these pathways.

The use of traditional plant medicines has been practiced for centuries, and despite a general insufficiency of supportive evidence concerning therapeutic efficacies, the use of herbal medicine continues to increase. The results of the present study confirmed previous observations that cytokine and MLDS activate the NF- $\mathrm{B}$ pathway and induce B-cell dysfunction. In addition, the results of this study demonstrate that FME has a $\beta$-cell protective effect. Specifically, FME completely counteracted the development of type 1 diabetes in response to MLDS, and this was paralleled by a completely preserved ß-cell mass. Since treatment with FME was not accompanied by serious side effects in mice, further clinical evaluation of FME is warranted to determine its value for the treatment of type 1 diabetes.

\section{Acknowledgements}

This work was supported by the Regional Research Centers Program of the Korean Ministry of Education and Human Resources Development through the Center for Healthcare Technology Development, and by a grant from the Ministry of Science and Technology (MoST)/Korea Science and Engineering Foundation (KOSEF) through the Vestibulocochlear Research Center (VCRC) at Wonkwang University (R13-2002-055-0000-0).

\section{References}

1. Atkinson MA and Maclaren NK: The pathogenesis of insulindependent diabetes mellitus. N Engl J Med 331: 1428-1436, 1994.

2. Papaccio G: Insulitis and islet microvasculature in type 1 diabetes. Histol Histopathol 8: 751-759, 1993.

3. Scherbaum WA: Etiology and pathogenesis of type 1 diabetes. Horm Metab Res Suppl 26: 111-116, 1992.

4. Hohmeier HE, Tran VV, Chen G, Gasa R and Newgard CB: Inflammatory mechanisms in diabetes: lessons from the $\beta$-cell. Int J Obes Relat Metab Disord 27 (Suppl 3): 12-16, 2003.

5. Arnush M, Heitmeier MR, Scarim AL, Marino MH, Manning PT and Corbett JA: IL-1 produced and released endogenously within human islets inhibits $\beta$ cell function. J Clin Invest 102 : 516-526, 1998.

6. Cetkovic-Cvrlje M and Eizirik DL: TNF- $\alpha$ and IFN- $\gamma$ potentiate the deleterious effects of IL-1ß on mouse pancreatic islets mainly via generation of nitric oxide. Cytokine 6: 399-406, 1994.

7. Kaneto H, Fujii J, Seo HG, Suzuki K, Matsuoka T, Nakamura M, Tatsumi H, Yamasaki Y, Kamada T and Taniguchi N: Apoptotic cell death triggered by nitric oxide in pancreatic $\beta$-cells. Diabetes 44: 733-738, 1995.

8. Stadler J, Billiar TR, Curran RD, Stuehr DJ, Ochoa JB and Simmons RL: Effect of exogenous and endogenous nitric oxide on mitochondrial respiration of rat hepatocytes. Am J Physiol 260: C910-C916, 1991.

9. Szkudelski T: The mechanism of alloxan and streptozotocin action in B cells of the rat pancreas. Physiol Res 50: 537-546, 2001.

10. Takasu N, Asawa T, Komiya I, Nagasawa Y and Yamada T: Alloxan-induced DNA strand breaks in pancreatic islets. Evidence for $\mathrm{H}_{2} \mathrm{O}_{2}$ as an intermediate. J Biol Chem 266: 2112-2114, 1991.

11. Tsuji A and Sakurai H: Generation of nitric oxide from streptozotocin (STZ) in the presence of copper(II) plus ascorbate: implication for the development of STZ-induced diabetes. Biochem Biophys Res Commun 245: 11-16, 1998.

12. Kwon NS, Lee SH, Choi CS, Kho T and Lee HS: Nitric oxide generation from streptozotocin. FASEB J 8: 529-533, 1994.

13. Turk J, Corbett JA, Ramanadham S, Bohrer A and McDaniel ML: Biochemical evidence for nitric oxide formation from streptozotocin in isolated pancreatic islets. Biochem Biophys Res Commun 197: 1458-1464, 1993.

14. Papaccio G, Pisanti FA, Latronico MV, Ammendola E and Galdieri M: Multiple low-dose and single high-dose treatments with streptozotocin do not generate nitric oxide. J Cell Biochem 77: 82-91, 2000. 
15. Elsner M, Guldbakke B, Tiedge M, Munday R and Lenzen S: Relative importance of transport and alkylation for pancreatic ß-cell toxicity of streptozotocin. Diabetologia 43: 1528-1533, 2000.

16. Carlsson PO, Flodstrom M and Sandler S: Islet blood flow in multiple low dose streptozotocin-treated wild-type and inducible nitric oxide synthase-deficient mice. Endocrinology 141: 2752-2757, 2000.

17. Lukic ML, Stosic-Grujicic S and Shahin A: Effector mechanisms in low-dose streptozotocin-induced diabetes. Dev Immunol 6: 119-128, 1998.

18. Flodstrom M, Tyrberg B, Eizirik DL and Sandler S: Reduced sensitivity of inducible nitric oxide synthase-deficient mice to multiple low-dose streptozotocin-induced diabetes. Diabetes 48: 706-713, 1999.

19. Giannoukakis N, Rudert WA, Trucco M and Robbins PD: Protection of human islets from the effects of interleukin-1B by adenoviral gene transfer of an IкB repressor. J Biol Chem 275: 36509-36513, 2000.

20. Heimberg H, Heremans Y, Jobin C, Leemans R, Cardozo AK, Darville M and Eizirik DL: Inhibition of cytokine-induced NF-KB activation by adenovirus-mediated expression of a NF- $\kappa \mathrm{B}$ super-repressor prevents $B$-cell apoptosis. Diabetes 50: 2219-2224, 2001.

21. Kim EK, Kwon KB, Koo BS, Han MJ, Song MY, Song EK, Han MK, Park JW, Ryu DG and Park BH: Activation of peroxisome proliferator-activated receptor- $\gamma$ protects pancreatic B-cells from cytokine-induced cytotoxicity via NFkB pathway. Int J Biochem Cell Biol 39: 1260-1275, 2007.

22. Mabley JG, Hasko G, Liaudet L, Soriano F, Southan GJ, Salzman AL and Szabo C: NFкB1 (p50)-deficient mice are not susceptible to multiple low-dose streptozotocin-induced diabetes. J Endocrinol 173: 457-464, 2002.

23. Kobayashi S, Kimura I and Kimura M: Inhibitory effect of magnosalin derived from Flos magnoliae on tube formation of rat vascular endothelial cells during the angiogenic process. Biol Pharm Bull 19: 1304-1306, 1996.

24. Kimura M, Suzuki J, Yamada T, Yoshizaki M, Kikuchi T, Kadota S and Matsuda S: Anti-inflammatory effect of neolignans newly isolated from the crude drug 'Shin-i' (Flos Magnoliae). Planta Med 291-293, 1985.
25. Moncada S, Palmer RM and Higgs EA: Nitric oxide: physiology, pathophysiology, and pharmacology. Pharmacol Rev 43: 109-142, 1991.

26. Kwon KB, Kim EK, Lim JG, Shin BC, Han SC, Song BK, Kim KS, Seo EA and Ryu DG: Protective effect of Coptidis Rhizoma on S-nitroso-N-acetylpenicillamine (SNAP)-induced apoptosis and necrosis in pancreatic RINm5F cells. Life Sci 76: 917-929, 2005.

27. Ho E, Chen G and Bray TM: $\alpha$-phenyl-tert-butylnitrone (PBN) inhibits $\mathrm{NF}_{\kappa} \mathrm{B}$ activation offering protection against chemically induced diabetes. Free Radic Biol Med 28: 604-614, 2000

28. Kim EK, Kwon KB, Han MJ, Song MY, Lee JH, Lv N, Ka SO, Yeom SR, Kwon YD, Ryu DG, Kim KS, Park JW, Park R and Park BH: Coptidis rhizoma extract protects against cytokineinduced death of pancreatic $\beta$-cells through suppression of NF-кB activation. Exp Mol Med 39: 149-159, 2007.

29. Blackwell TS and Christman JW: The role of nuclear factor-кB in cytokine gene regulation. Am J Respir Cell Mol Biol 17: 3-9, 1997.

30. Richmond A: NF-кB, chemokine gene transcription and tumour growth. Nat Rev Immunol 2: 664-674, 2002.

31. Kim EK, Kwon KB, Han MJ, Song MY, Lee JH, Lv N, Choi KB, Ryu DG, Kim KS, Park JW and Park BH: Inhibitory effect of Artemisia capillaris extract on cytokine-induced nitric oxide formation and cytotoxicity of RINm5F cells. Int J Mol Med 19: 535-540, 2007.

32. Kim EK, Kwon KB, Song MY, Seo SW, Park SJ, Ka SO, Na L, Kim KA, Ryu DG, So HS, Park R, Park JW and Park BH: Genistein protects pancreatic B cells against cytokine-mediated toxicity. Mol Cell Endocrinol 278: 18-28, 2007.

33. Lv N, Song MY, Kim EK, Park JW, Kwon KB and Park BH: Guggulsterone, a plant sterol, inhibits $N F-\kappa B$ activation and protects pancreatic $\beta$ cells from cytokine toxicity. Mol Cell Endocrinol 289: 49-59, 2008.

34. Oyadomari S, Takeda K, Takiguchi M, Gotoh T, Matsumoto M, Wada I, Akira S, Araki E and Mori M: Nitric oxide-induced apoptosis in pancreatic $B$ cells is mediated by the endoplasmic reticulum stress pathway. Proc Natl Acad Sci USA 98: 10845-10850, 2001. 